Original Research Article

\title{
Assessment on antinociceptive actions of soluble fractions derived from edible mollusc (Bellamya bengalensis Lam.)
}

\author{
Anjan Adhikari ${ }^{1 *}$, Sangita Bhattacharya ${ }^{1}$, Abhijt Chanda ${ }^{2}$, Tapas Kumar Sur ${ }^{3}$
}

${ }^{1}$ Department of Pharmacology,

R G Kar Medical College,

Kolkata 700004, West Bengal,

India

${ }^{2}$ School of Bioscience and

Engineering, Jadavpur

University. Kolkata 700032,

West Bengal, India

${ }^{3}$ Department of Pharmacology, I.P.G.M.E. \& R, Kolkata, West Bengal, India

Received: 12 October 2017

Accepted: 03 November 2017

*Correspondence to:

Dr. Anjan Adhikari,

Email: dradhikarianjankolkata

@gmail.com

Copyright: (C) the author(s), publisher and licensee Medip Academy. This is an openaccess article distributed under the terms of the Creative Commons Attribution NonCommercial License, which permits unrestricted noncommercial use, distribution, and reproduction in any medium, provided the original work is properly cited.

\begin{abstract}
Background: Bellamya bengalensis, an edible bivalve mollusc is traditionally used in the treatment of joint pain, bone fracture, jaundice and eye infections. Present study was designed to find out the most potent analgesic fractions derived from the body mass of Bellamya bengalensis.

Methods: The test specimen was collected, identified and fractionated with solvent medium like, phos phate buffer saline (PB), ethyl acetate (EB), methanol (MB) and chloroform (CB). Protein concentration of each fraction was determined. The antinociceptive activities were measured either by thermal models like, hot plate and tail immersion (central analgesic action) or by chemical model like acetic acid induced writhing (peripheral analgesic action) in mice. Diclofenac sodium was used as analgesic standard.

Results: Significant peripheral and central analgesic activity showed by phosphate buffer saline fraction at $100 \mathrm{mg} / \mathrm{kg}$, even better than diclofenac standard at $10 \mathrm{mg} / \mathrm{kg}$. In hot plate and tail immersion tests, phosphate buffer saline showed the highest activity followed by methanol, chloroform and ethyl acetate fraction respectively. However, in case of peripheral analgesic experiment, phosphate buffer fraction exhibited maximum writhing inhibitory properties and that was followed by chloroform, methanol and ethyl acetate fraction respectively.

Conclusions: Phosphate buffer saline fraction of Bellamya bengalensis showed maximum potential central and peripheral analgesic activity than any other fractions.
\end{abstract}

Keywords: Analgesic, Bellamya bengalensis, Eddy’s hot plate, Mice, Mollusc

\section{INTRODUCTION}

Pain is a noxious stimuli which involves sensory, emotional and cognitive experience and leads to from potential tissue damage. ${ }^{1}$ Severe pain needs the use of strong analgesics which can act peripherally by blocking the generation of impulses at chemoreceptor site of pain or can act centrally by raising the threshold and altering the physiological response to pain. ${ }^{2}$ Non Steroidal anti- inflammatory drugs (NSAIDs) is still the backbone therapy in the treatment of pain by inhibiting cyclooxygenase, the enzyme which catalyzes the ratelimiting step in the metabolic conversion of arachidonic acid to prostaglandins and related eicosanoids.,4 Unfortunately, chronic use of NSAIDs may cause of health hazards, range from dyspepsia to gastric irritation or bleeding and acute renal failure. ${ }^{4,5}$ 
The ethnopharmacological knowledge provides enough information on the folklore practices and traditional aspects of therapeutically important natural products. ${ }^{6}$ Plant based drugs are used as the source of traditional medicine since ancient times in India. But use of animal products, as an important component of traditional medicine has been much less studied in the country. Molluscs are a diverse group of organisms produces many medicinally significant metabolites. The conotoxin from the cone-shell snail inhibits pain as well as accelerates the recovery of injured nerves. ${ }^{8}$ Bellamya bengalensis, a freshwater mollusc, (class: Gastropoda) are also used in the treatment of various diseases such as arthritis, as thma, and conjunctivitis. ${ }^{9}$ It has been documented in earlier works, that the extrapallial fluid of Bellamya bengalensis possess antiarthritic and analgesic activity. ${ }^{10}$

Mollusc usually consists of hard shell, mantle and a foot. The whole soft body lies within an enlarged mantle cavity. Elutions with different polar and non polar solvents convey diverse chemical molecules. Phosphate buffer saline is a polar solution that mimics the physiological body fluid, whereas the chloroform, methanol and ethyl acetate have non polar characteristics. ${ }^{11,12}$ Hence, the present study was aim to explore the maximu $\mathrm{m}$ antinociceptive properties of different fractionations eluted with polar to non-polar solvents from soft body mass of Bellamya bengalensis.

\section{METHODS}

\section{Collection and identification of the mollusc}

Bellamya bengalensis was collected from Kolkata, West Bengal, India. The bivalve mollusc was authenticated from Zoological Survey of India, Kolkata (No:1242/lot No-63), as Bellamya bengalensis Lam. of the Viviparidae family.

\section{Sample preparation}

The freshwater mollusc was collected live from the ponds and was washed well with distilled water for three times consecutively. The shell was carefully removed and the whole mass was eluted with four separate solventsphosphate buffer saline, ethyl acetate, methanol and chloroform. In brief, the body mass of Bellamya bengalensis Lam. was left overnight at $4^{\circ} \mathrm{C}$ in the respective solvents. Thereafter, mass was grinded, followed by spinning down for 5000rpm for $10 \mathrm{~min}$ and filtered through Whatman filter paper. Four eluted fractionations were marked as PB for phosphate buffer saline, MB for methanol, EB for ethyl acetate and CB for chloroform.

\section{Animals}

Acute toxicity and analgesic studies were done with Swiss albino mice weighing 20-25g. The animal experiments were conducted in accordance with the accepted principles for laboratory animal use and care. The animals were kept in the animal house, maintaining standard condition and fed with proper diet and water ad libitum.

\section{Acute toxicity study}

Acute oral toxicity study of all the four fractions of mollusc namely $\mathrm{PB}, \mathrm{MB}, \mathrm{EB}, \mathrm{CB}$ was performed according to Organization for Economic Cooperation and Development (OECD) guidelines 423. ${ }^{13}$ Three animals in each group, albino female mice weighing $20-25 \mathrm{~g}$ were used in each group of the study. All the four fractions were administered oral single dose in progressive manner up to $2 \mathrm{~g} / \mathrm{kg}$ of mass body weight of mollusc. The animals were observed for any sign of toxicity, morbidity or mortality for initially $24 \mathrm{~h}$ and followed by next $72 \mathrm{~h}$.

\section{In-vivo analgesic study}

\section{Thermal nociception by Eddy's hot plate}

Ten groups of Swiss mice, where $\mathrm{N}=6$ in each group, weighing $20-25 \mathrm{~g}$ were selected for this study. The group divisions are shown in Table 1.

Table 1: Group division for in-vivo analgesic activity.

\begin{tabular}{|lll|}
\hline Groups & Treatment & Dose (Oral) \\
\hline Control & Normal saline & $0.5 \mathrm{ml} / \mathrm{kg} \mathrm{b}$ b.w. \\
\hline Standard & Diclofenac Sodium & $10 \mathrm{mg} / \mathrm{kg}$ b.w. \\
\hline \multirow{2}{*}{ PB I } & $\begin{array}{l}\text { PBS fraction of } B . \\
\text { bengalensis }\end{array}$ & $\begin{array}{l}100 \mathrm{mg} / \mathrm{kg} \\
\text { b.w. }\end{array}$ \\
\hline \multirow{2}{*}{ PB II } & $\begin{array}{l}\text { PBS fraction of } B . \\
\text { bengalensis }\end{array}$ & $\begin{array}{l}200 \mathrm{mg} / \mathrm{kg} \\
\text { b.w. }\end{array}$ \\
\hline \multirow{2}{*}{ EB I } & $\begin{array}{l}\text { Ethyl acetate fraction of } \\
\text { B. bengalensis }\end{array}$ & $\begin{array}{l}100 \mathrm{mg} / \mathrm{kg} \\
\text { b.w. }\end{array}$ \\
\hline \multirow{2}{*}{ EB II } & $\begin{array}{l}\text { Ethyl acetate fraction of } \\
\text { B. bengalensis }\end{array}$ & $\begin{array}{l}200 \mathrm{mg} / \mathrm{kg} \\
\text { b.w. }\end{array}$ \\
\hline \multirow{2}{*}{ MB I } & $\begin{array}{l}\text { Methanolfraction of } B . \\
\text { bengalensis }\end{array}$ & $\begin{array}{l}100 \mathrm{mg} / \mathrm{kg} \\
\text { b.w. }\end{array}$ \\
\hline \multirow{2}{*}{ MB II } & $\begin{array}{l}\text { Methanolfraction of } B . \\
\text { bengalensis }\end{array}$ & $\begin{array}{l}200 \mathrm{mg} / \mathrm{kg} \\
\text { b.w. }\end{array}$ \\
\hline \multirow{2}{*}{ CB I } & $\begin{array}{l}\text { Chloroform fraction of } \\
\text { B. bengalensis }\end{array}$ & $\begin{array}{l}100 \mathrm{mg} / \mathrm{kg} \\
\text { b.w. }\end{array}$ \\
\hline \multirow{2}{*}{ CB II } & $\begin{array}{l}\text { Chloroform fraction of } \\
\text { B. bengalensis }\end{array}$ & $\begin{array}{l}200 \mathrm{mg} / \mathrm{kg} \\
\text { b.w. }\end{array}$ \\
\hline
\end{tabular}

Eddy's hot plate (Orchid Scientifics, India) was used for this experimentation. The constant temperature was fixed at $55 \pm 1^{\circ} \mathrm{C}$. All mice were placed individually on the hot plate after $30 \mathrm{~min}, 60 \mathrm{~min}$ and $90 \mathrm{~min}$ after drug administration. The time interval of pain responds either by paw licking or jumping was recorded. The cut of time for the response was $15 \mathrm{sec} .^{14,15}$

\section{Tail-immersion method}

Ten groups, each group, consisting of six Swiss mice weighing $20-25 \mathrm{~g}$ were randomly selected as above. After administration of the test drug, the lower end of the tail of 
the animal was dipped in hot water up to $5 \mathrm{~cm}$. Temperature of the water was maintained at $55 \pm 1^{\circ} \mathrm{C}$. The sudden withdrawal of tail from the water was recorded as response. The cut off time was $10 \mathrm{sec}$. The reaction time was recorded just before the administration of the drug $(0$ $\min$ ) and was compared with the response at $60 \mathrm{~min}$ and 90 min after drug adminis tration. ${ }^{15,16}$

\section{Acetic acid induced writhing}

Swiss albino mice of either sex (20-25g) were divided in ten groups comprising of six animals each, as described above. Each mouse was injected with $0.6 \%$ acetic acid intraperitoneally, 30 minutes after the administration of test drugs at different doses in oral route. Number of writhes was counted for $10 \mathrm{~min}$ after acetic acid injection and the degree of analgesia was calculated as follows: ${ }^{16}$

\section{Degree of analgesia $=$}

(No. of writhing in control-no. of writhing in of test) X100 No. of writhing in control

\section{Statistical analysis}

The results were presented as Mean \pm standard error of mean. The data were statistically analyzed by ANOVA and Dunnett's post-hoc test. The differences were considered statistically significant when $\mathrm{p} \leq 0.05$ and $\mathrm{p} \leq 0.01$.

\section{RESULTS}

\section{Acute toxicity study}

All the test fractions of Bellamya bengalensis L. namely, $\mathrm{PB}, \mathrm{MB}, \mathrm{EB}$ and $\mathrm{CB}$ were found to be safe up to oral dose of $2 \mathrm{~g} / \mathrm{kg}$ body weight in mice.

\section{Thermal nociception by Eddy's hot plate method}

Results of thermal nociception activity by hot plate method are enumerated in Table 2 . The responses were specified at $30 \mathrm{~min}, 60 \mathrm{~min}$ and $90 \mathrm{~min}$ after administration of the test fractions. The controls, which were treated with normal saline, did not show any significant change throughout the $90 \mathrm{~min}$ observation. The test sample, PB at the oral dose of $100 \mathrm{mg} / \mathrm{kg}$ body weight showed significant analgesic activity by increasing the pain latency from $3.1 \pm 0.27 \mathrm{sec}$ to $13.5 \pm 0.40 * * \mathrm{sec}$. $\mathrm{MB}$ and $\mathrm{CB}$ were also showed analgesic activity at $100 \mathrm{mg} / \mathrm{kg}$ dose which increased the latency period to $11.6 \pm 0.36^{* *} \mathrm{sec}$ and $9.0 \pm 0.96 * *$ respectively when compared to control. Standard analgesic, Diclofenac sodium at the oral dose of $10 \mathrm{mg} / \mathrm{kg}$ was significantly increased the latency period from $2.9 \pm 0.15 \sec$ to $12.0 \pm 0.44^{* *} \sec$ (Table 2).

Table 2: Bellamya bengalensis L. fractions on reaction time in hot plate test.

\begin{tabular}{|llllll|}
\hline Groups & Treatment/Dose & Reaction time in sec (Mean \pm SEM) & & \\
\hline & & $\mathbf{0}$ min & $\mathbf{3 0}$ min & $\mathbf{6 0}$ min & $\mathbf{9 0}$ min \\
\hline Control & $0.5 \mathrm{ml} / \mathrm{kg}$ saline & $3 \pm 0.25$ & $3.6 \pm 0.42$ & $3.8 \pm 0.30$ & $3.1 \pm 0.64$ \\
\hline Standard & $10 \mathrm{mg} / \mathrm{kg} \mathrm{Diclofenac}$ & $2.9 \pm 0.15$ & $8.1 \pm 0.40^{* *}$ & $12.4 \pm 0.82^{* *}$ & $12.0 \pm 0.44^{* *}$ \\
\hline PB I & $100 \mathrm{mg} / \mathrm{kg} \mathrm{PB}$ & $3.1 \pm 0.27$ & $7.6 \pm 1.28^{* *}$ & $12.0 \pm 1.71^{* *}$ & $13.5 \pm 0.40^{* *}$ \\
\hline PB II & $200 \mathrm{mg} / \mathrm{kg} \mathrm{PB}$ & $2.9 \pm 0.80$ & $6.3 \pm 0.33^{*}$ & $6.8 \pm 0.81^{*}$ & $6.3 \pm 0.22^{*}$ \\
\hline EB I & $100 \mathrm{mg} / \mathrm{kg} \mathrm{EB}$ & $3.0 \pm 0.58$ & $5.9 \pm 0.74$ & $5.6 \pm 1.30$ & $5.5 \pm 0.81$ \\
\hline EB II & $200 \mathrm{mg} / \mathrm{kg} \mathrm{EB}$ & $3.0 \pm 0.25$ & $5.8 \pm 0.98$ & $5.7 \pm 1.23$ & $5.8 \pm 0.87$ \\
\hline MB I & $100 \mathrm{mg} / \mathrm{kg} \mathrm{MB}$ & $2.9 \pm 0.15$ & $7.4 \pm 0.63^{* *}$ & $11.6 \pm 0.97^{* *}$ & $11.6 \pm 0.36^{* *}$ \\
\hline MB II & $200 \mathrm{mg} / \mathrm{kg} \mathrm{MB}$ & $3.0 \pm 0.25$ & $6.8 \pm 0.85^{*}$ & $6.8 \pm 0.92^{*}$ & $6.7 \pm 0.64^{*}$ \\
\hline CB I & $100 \mathrm{mg} / \mathrm{kg} \mathrm{CB}$ & $2.8 \pm 0.25$ & $7.5 \pm 0.33^{* *}$ & $8.0 \pm 0.49^{* *}$ & $9.0 \pm 0.96^{* *}$ \\
\hline CB II & $200 \mathrm{mg} / \mathrm{kg} \mathrm{CB}$ & $3.0 \pm 0.25$ & $7.5 \pm 0.61^{* *}$ & $7.45 \pm 0.96^{* *}$ & $7.55 \pm 0.81^{* *}$ \\
\hline
\end{tabular}

Results are expressed as Mean \pm SEM ( $n=6)$; Statistical analysis was done by One way Anova followed by Dunnett test as post hoc analy sis where $* \mathrm{p}<0.05$ and $* * \mathrm{p}<0.01$

\section{Tail-immersion method}

The normal reaction time of tail flick response in mice to warm water was nearly 1.8-1.9 sec. In this study, test drug fraction, PB showed maximu $\mathrm{m}$ analgesic activity at a dose of $100 \mathrm{mg} / \mathrm{kg}$ and it reduced reaction time of pain sensation from $1.8 \pm 0.27 \mathrm{sec}$ to $6.0 \pm 0.82 * * \mathrm{sec}$ within $90 \mathrm{~min}$. Diclofenac sodium lowered the reaction time, the indicator of pain sensation was $1.8 \pm 0.28$ to $5.0 \pm .56^{* *}$.
However, higher doses of PB did not showed any significant increase in response time. Moreover, MB and $\mathrm{CB}$ also showed significant enhancement in reaction time, but EB did not respond (Table 3).

\section{Acetic acid induced writhing}

The study showed that $\mathrm{PB}$ at $100 \mathrm{mg} / \mathrm{kg}$ dose significantly reduced the writhing response when compared to control. 
$\mathrm{PB}$ at $100 \mathrm{mg} / \mathrm{kg}$ was showed $60.48 \%$ reduction in writhes, whereas, Diclofenac was showed $40.90 \%$ decrease in writhes compared to control. However, CB at $100 \mathrm{mg} / \mathrm{kg}$ was showed $48.25 \%$ reduction and MB exhibited $38.11 \%$ reduction. EB was capable to reduced only $20.62 \%$ writhing (Table 4).

Table 3: Bellamya bengalensis $\mathrm{L}$. fractions in tail immersion test.

\begin{tabular}{|lllll|}
\hline Groups & Treatment/ dose & \multicolumn{2}{l}{ Reaction time in sec (Mean \pm SEM) } & ( \\
\hline Control & $0.5 \mathrm{ml} / \mathrm{kg}$ saline & 0 min & $\mathbf{3 0 ~}$ min & $1.9 \pm 0.30$ \\
\hline Standard & $10 \mathrm{mg} / \mathrm{kg} \mathrm{Diclofenac}$ & $1.8 \pm 0.11$ & $1.8 \pm 0.21$ & $5.0 \pm .56^{* *}$ \\
\hline PB I & $100 \mathrm{mg} / \mathrm{kg} \mathrm{PB}$ & $1.8 \pm 0.27$ & $5.3 \pm 0.82^{*}$ & $6.0 \pm 0.82^{* *}$ \\
\hline PB II & $200 \mathrm{mg} / \mathrm{kg} \mathrm{PB}$ & $1.7 \pm 0.33$ & $4.1 \pm 0.92^{*}$ & $4.9 \pm 0.90^{*}$ \\
\hline EB I & $100 \mathrm{mg} / \mathrm{kg} \mathrm{EB}$ & $1.9 \pm 0.58$ & $2.5 \pm 0.66$ & $2.7 \pm 0.96$ \\
\hline EB II & $200 \mathrm{mg} / \mathrm{kg} \mathrm{EB}$ & $2.1 \pm 0.28$ & $2.7 \pm 0.58$ & $2.9 \pm 0.74$ \\
\hline MB I & $100 \mathrm{mg} / \mathrm{kg} \mathrm{MB}$ & $1.9 \pm 0.66$ & $2.5 \pm 0.30$ & $2.9 \pm 0.67$ \\
\hline MB II & $200 \mathrm{mg} / \mathrm{kg} \mathrm{MB}$ & $2.0 \pm 0.88$ & $3.4 \pm 0.85^{*}$ & $3.9 \pm 0.96^{*}$ \\
\hline CB I & $100 \mathrm{mg} / \mathrm{kg} \mathrm{CB}$ & $2.0 \pm 0.25$ & $2.8 \pm 0.63$ & $3.0 \pm 0.88$ \\
\hline CB II & $200 \mathrm{mg} / \mathrm{kg} \mathrm{CB}$ & $1.8 \pm 0.42$ & $3.0 \pm 0.68^{*}$ & $3.7 \pm 0.93^{*}$ \\
\hline
\end{tabular}

Results are expressed as Mean \pm SEM ( $n=6)$; Statistical analysis was done by One way Anova followed by Dunnett test; $* \mathrm{p}<0.05$ and $* * \mathrm{p}<0.01$.

Table 4: Bellamya bengalensis $\mathrm{L}$. fractions in acetic acid induced writhing.

\begin{tabular}{|lll|}
\hline Groups & Treatment/Dose & $\begin{array}{l}\text { Degree of analgesia } \\
\text { (mean } \\
\text { percentage } \pm \text { SEM) }\end{array}$ \\
\hline Standard & $\begin{array}{l}10 \mathrm{mg} / \mathrm{kg} \\
\text { Diclofenac sodium }\end{array}$ & $40.90 \pm 1.01^{* *}$ \\
\hline PB I & $100 \mathrm{mg} / \mathrm{kg} \mathrm{PB}$ & $60.48 \pm 1.06^{* *}$ \\
\hline PB II & $200 \mathrm{mg} / \mathrm{kg} \mathrm{PB}$ & $58.32 \pm 1.22^{* *}$ \\
\hline EB I & $100 \mathrm{mg} / \mathrm{kg} \mathrm{EB}$ & $20.62 \pm 1.10^{*}$ \\
\hline EB II & $200 \mathrm{mg} / \mathrm{kg} \mathrm{EB}$ & $17.13 \pm 2.64 *$ \\
\hline MB I & $100 \mathrm{mg} / \mathrm{kg} \mathrm{MB}$ & $38.11 \pm 2.07^{*}$ \\
\hline MB II & $200 \mathrm{mg} / \mathrm{kg} \mathrm{MB}$ & $32.86 \pm 1.29 * *$ \\
\hline CB I & $100 \mathrm{mg} / \mathrm{kg} \mathrm{CB}$ & $48.25 \pm 1.37 * *$ \\
\hline CB II & $200 \mathrm{mg} / \mathrm{kg} \mathrm{CB}$ & $40.55 \pm 1.54 * *$ \\
\hline
\end{tabular}

\section{DISCUSSION}

Pain is classified into two types; one is fast pain which is mediated by $A_{\delta}$ fibers and another is slow pain which is mediated by $\mathrm{C}$ fibers whereas, nociception is the response of the sensory nervous system to the harmful noxious stimuli. ${ }^{17,18}$ Present study compared the anti-nociceptive activity of the four different fractions of Bellamya bengalensis Lam. Assessment of analgesic actions of test fractions were done following thermal pain stimulus like, hot plate and tail immersion as well as chemical mediator of pain like acetic acid induced writhing. All the four fractions prepared from the body mass of mollusc namely
$\mathrm{PB}, \mathrm{CB}, \mathrm{MB}$ and $\mathrm{EB}$ were found safe in mice even at oral dose of $2 \mathrm{~g} / \mathrm{kg}$.

The phosphate buffer saline fraction of mollusc showed the most potent analgesic activity for both central and peripheral pathways. Hot plate and tail immersion method was used to assess the central analgesic activity. These models are based on the sensitization of the nociceptors of the sensory neurons with thermal stimuli. The contributions of endogenous substances like prostaglandins are limited in these cases. ${ }^{19}$ Hot plate is also used to study non-inflammatory and acute analgesia. It is established that any agent that increases the latency period by hot plate method are acting centrally. ${ }^{20}$ In the present study, PB fractions of Bellamya bengalensis Lam. showed maximum significant increase of latency period or analgesic properties in hot plate and tail immersion method followed by $\mathrm{MB}>\mathrm{CB}>\mathrm{EB}$. Therefore, the phosphate buffer saline extract of body mass of the mollusc may have central analgesic activity.

Acetic acid writhing in mice is a standard model for evaluation of peripheral analgesic activity. Acetic acid is a chemical irritant that stimulates the local peritoneal receptors by releasing serotonin, bradykinin, histamine, prostaglandins (PGs). ${ }^{21}$ Intraperitoneal administration of the chemical stimulants signalling to release of PGs especially, $\mathrm{PGE}_{2}, \mathrm{PGF}_{2} \alpha$ and lipooxygenase that mediated to elicit the visceral pain and abdominal constrictions. ${ }^{22,23}$ There are very few studies exploring analgesic activity of Bellamya bengalensis. Previous report showed that the extrapallial fluid of Bellamya bengalensis has dose dependent analgesic action. ${ }^{10}$ Another study reported foot muscle extract of Bellamya bengalensis has significant 
central and peripheral analgesic activity. ${ }^{20}$ In the present study, among the different fractions eluted from body mass of Bellamya bengalensis PB fraction showed maximu $\mathrm{m}$ significant analgesic action at $100 \mathrm{mg} / \mathrm{kg}$ followed by $\mathrm{CB}>\mathrm{MB}>\mathrm{EB}$. From the above findings, therefore it may be suggested that the peripheral analgesic activity of $\mathrm{PB}$ fraction may be due to inhibition of prostaglandin mediated pathway for pain regulation.

In the present study, though phosphate buffer saline fraction showed maximum analgesic action but other two non-polar i.e., methanol and chloroform fractions have also mild analgesic properties.

Hence, it may be assumed that the components responsible for analgesic properties of body mass of Bellamya bengalensis have both polar and non-polar characteristics. Further, purification is required to characterization the compounds responsible for anti-nociceptive properties of the mollusc, which is presently continuing in our laboratory.

\section{ACKNOWLEDGEMENTS}

The authors would like to express gratitude to the Principal, R. G. Kar Medical College, Kolkata for providing support in every aspect for conducting the research. Authors also acknowledge support from Jadavpur University, Kolkata in this research.

\section{Funding: No funding sources}

Conflict of interest: No

Ethical approval: The study was approved by the Institutional Animal Ethics Committee (No: RKC/IAEC/13/19)

\section{REFERENCES}

1. Dubin AE, Patapoutian A. Nociceptors: the sensors of the pain pathway. The Journal of Clinical Investigation. 2010;120(11):3760-72.

2. Siddalingappa CM, Rajesh T, Kudagi BL, Krishnakanth K, Sujith TR. Evaluation of analgesic and anti-inflammatory activities of Tinospora cordifolia in rodents. Int $\mathrm{J}$ Basic Medical Science. 2012;2:306-11.

3. Maroon JC, Bost JW, Maroon A. Natural antiinflammatory agents for pain relief. Surgical Neurol Int. 2010; 1:80.

4. Vane JR, Botting RM. The mechanism of action of as pirin. Thromb Res. 2003;110:255-8.

5. Marcum ZA, Hanlon JT. Recognizing the risks of chronic non-steroidal anti-inflammatory drug use in older adults. The annals of Long-term Care. 2010;18:24-7.

6. Ravishankar B, Shukla V. Indian Systems of Medicine: A brief profile. African J Trad Compl Alternative Med. 2007;4:319-37.

7. Saha S, Guria T, Singha T, Maity TK. Evaluation of analgesic and anti-inflammatory activity of chloroform and methanol extracts of Centella asiatica Linn. ISRN Pharmacol. 2013:6-12.

8. Jha RK, Zi-rong X. Biomedical compounds from marine organisms. Marine Drugs. 2004;2:123-46.

9. Prabhakar AK, Roy SP. Ethnomedicinal uses of some shell fishes by people of Kosi river basin of north Bihar, India. Ethnomed. 2009;3:1-4.

10. Adhikari A, Bhattacharya S, Sur TK, Bandopadhyay SK. Anti-inflammatory activities of Indian fresh water edible mollusca. IOSR J Pharmacy Biological Sci. 2015;10:61-6.

11. Kiran N, Siddiqui G, Khan AN, Ibrar K, Tushar P. Extraction and screening of bioactive compounds with antimicrobial properties from selected species of mollusc and Crustacean. J Clin Cell Immunol. 2014;5:1-9.

12. Lawrence SB, Darko G, Oklu N, Anson-Yevu C, Ababio A, Li G. Antimicrobial and antioxidant activities of ethyl acetate and methanol extracts of Littorina littorea and Galatea paradoxa. Cogent Chemistry. 2016;2(1).

13. OECD guidelines 423. Guideline for the testing of chemicals. Acute oral toxicity in animals. Adopted $21^{\text {st }}$ September; 1998.

14. Vogel HG. Analgesic, anti-inflammatory, and antipyretic activity. Drug Discovery and Evaluation Pharmacological Assays. $2^{\text {nd }}$ Ed. New York: Springer; 2002:670.

15. Hossain H, Ismet JA, Howlader SI, Dey SK, Hira A, Ahmed A. Phytochemical screening and antinociceptive properties of the ethanolic leaf extract of Trema Cannabina Lour. Adv Pharmaceut Bull. 2013;3:103-8.

16. Ganeshpurkar A, Rai G. Experimental evaluation of analgesic and anti-inflammatory potential of Oyster mushroom Pleurotus florida. Indian $\mathrm{J}$ Pharmacol. 2013;45:66-70.

17. Dubin AE, Patapoutian A. Nociceptors: the sensors of the pain pathway. The $\mathrm{J}$ of Clin Investigation. 2010; 120(11):3760-72.

18. Garland EL. Pain Processing in the Human Nervous System: A Selective Review of Nociceptive and Biobehavioral Pathways. Primary care. 2012;39(3):561-71.

19. Ezeja M, Omeh Y, Ezeigbo I, Ekechukwu A. Evaluation of the analgesic activity of the methanolic stem bark extract of Dialium guineense (Wild). Ann Med Health Sci Res. 2011;1:55-62.

20. Sarkar A, Datta P, Gomes A, Gupta A, Gomes A. Antiosteoporosis and anti-osteoarthritis activity of fresh water snail (Viviparous bengalensis) flesh extract in experimental animal model. Open $\mathrm{J}$ Rheumatol Autoimmune Dis. 2013;3:10-7.

21. Sabina EP, Chandel S, Rasool MK. Evaluation of analgesic, antipyretic and ulcerogenic effect of Withaferin A. Int J Integrative Biol. 2009;6:52-6.

22. Suresha RN, Amoghimath S, Vaibhavi PS, Shruthi SL, Jayanthi MK, Kalabharathi HL. Evaluation of analgesic activity of perindopril in albino mice. J Adv Pharmaceut Tech Res. 2014;5:129-33. 
23. Mishra D, Ghosh G, Kumar PS, Panda PK. An experimental study of analgesic activity of selective COX-2 inhibitor with conventional NSAIDs. Asian J Pharm Clin Res. 2011;4:78-81.
Cite this article as: Adhikari A, Bhattacharya $S$, Chanda A, Sur TK. Assessment on antinociceptive actions of soluble fractions derived from edible mollusc (Bellamya bengalensis Lam.). Int J Basic Clin Pharmacol 2017;6:2916-21. 